\title{
Pengaruh Capital Adequacy Ratio, Financing to Deposit Ratio, Biaya Operasional Pendapatan Operasional dan Non-Performing Financing Terhadap Profitabilitas Bank Umum Syariah di Indonesia
}

\author{
Muhammad Ikhwan Nugraha, Arfie Yasrie \\ STIMI Banjarmasin \\ Email : mnugraha855@gmail.com
}

\begin{abstract}
ABSTRAK
Penelitian ini bertujuan untuk menganalisa pengaruh dari beberapa variabel terhadapa perubahan ROA pada Bank Umum Syariah (BUS). Metode Penelitian, sesuai dengan tujuan penelitian yang telah dirumuskan, maka penelitian ini menggunakan pola eksplanasi (level of explanation) yaitu penelitian yang bermaksud menjelaskan kedudukan faktor-faktor yang diteliti serta hubungan antara satu faktor dengan faktor yang lain. Variabel-variabel independen yang digunakan adalah CAR atau Capital Adequacy Ratio (X1), FDR atau Financing to Deposit Ratio (X2), BOPO atau Biaya Operasional Pendapatan Operasional (X3) dan NPF atau Non Performing Financing (X4). Sedangkan variabel dependen adalah profitabilitas yang diwakili oleh ROA atau Return on Assets (Y). Populasi dari penelitian ini adalah data-data baik variabel-variabel dependen maupun variabel independen BUS di Indonesia, sejak tahun 2015 sampai tahun 2019. Total sampel adalah 60 data yang ditentukan dengan metode purposive sampling. Data tersebut diambil dari laporan keuangan dari tiap BUS dan situs lain yang bereputasi. Analisis data dilakukan dengan asumsi klasik dan hipotesis diuji dengan Analisis Regresi Berganda dengan menggunakan alat bantu analisis program SPSS 19.0 for Windows. Hasil dari penelitian ini menunjukkan bahwa FDR dan BOPO mempunyai pengaruh signifikan terhadap ROA, sedangkan CAR dan NPF tidak memiliki pengaruh signifikan terhadap ROA. Secara simultan CAR (X1), FDR (X2), BOPO (X3) dan NPF (X4) secara bersama-sama berpengaruh signifikan terhadap ROA (Y) BUS di Indonesia.
\end{abstract}

Kata Kunci: CAR, FDR, BOPO, NPF, ROA, profitabilitas

\section{PENDAHULUAN}

Bank Umum berdasarkan Kegiatan Usaha selanjutnya disebut BUKU adalah pengelompokan Bank berdasarkan Kegiatan Usaha yang disesuaikan dengan Modal Inti yang dimiliki. BUKU 1 memiliki modal kurang dari 1 triliun rupiah, BUKU 2 punya modal 1 sampai 5 triliun rupiah, BUKU 3 memiliki modal 5 sampai 30 triliun rupiah, sedangkan BUKU 4 memiliki modal paling sedikit 30 triliun rupiah. Bank Umum Syariah (BUS) masih menempati BUKU 2 dan BUKU 3 dengan modal tidak lebih dari 30 triliun rupiah. Hal ini berbeda dengan bank konvensional di mana terdapat beberapa bank yang memiliki modal di atas 30 triliun rupiah, seperti Bank BRI, Bank Mandiri, Bank BNI dan Bank BCA. Modal seluruh BUS ketika dijumlah hanya mencapai 39 triliun rupiah.

Penilaian kesehatan bank bertujuan untuk mengetahui apakah bank tersebut mengalami kondisi yang sehat, kurang sehat atau sakit. Bila BUS punya kinerja buruk, bukan tidak mungkin pemilik dana akan mengalihkan dananya ke bank konvensional. Ukuran profitabilitas yang umum dipakai adalah ROA. Semakin besar ROA yang dimiliki bank, 
maka semakin besar pula tingkat keuntungan yang dicapai bank tersebut dan semakin besar pula posisi bank tersebut dari sisi penggunaan aset.

Modal adalah faktor penting bagi bank untuk memastikan kecukupan modal dan cadangan untuk mengatasi risiko yang mungkin timbul. Variabel CAR memengaruhi tingkat profitabilitas bank syariah (Sumarlin, 2016). Menurut Peraturan Bank Indonesia Nomor 14/18/PBI/2012, CAR mempunyai nilai minimal sebesar $8 \%$. Tingginya rasio CAR berarti modal bank tersebut juga besar, hal ini akan meningkatkan kepercayaan masyarakat kepada bank yang ujungnya akan meningkatkan profitabilitas bank. Variabel FDR memengaruhi tingkat profitabilitas bank syariah (Sumarlin, 2016). Semakin tinggi FDR maka semakin tinggi dana yang disalurkan ke nasabah peminjam, sehingga Profitabilitas semakin meningkat.

Variabel BOPO adalah rasio perbandingan antara biaya operasional dengan pendapatan operasional dalam mengukur tingkat efesiensi dan kemampuan bank dalam melakukan kegiatan operasinya. Semakin kecil biaya operasional, dengan pendapatan relatif tetap, maka profitabilitas yang diperoleh semakin besar. Variabel NPF atau rasio pembiayaan bermasalah merupakan salah satu indikator kunci untuk menilai kinerja bank. Semakin tinggi NPF maka akan semakin kecil pula laba yang diperoleh. Penelitian ini mencoba mengetahui dan menguji kembali pergerakan ROA bank umum syariah yang diwakili oleh ROA sebagai sampel penelitian dengan rentang waktu tahun 2015 sampai 2019 menggunakan parameter yang berhubungan atau diduga berhubungan pada pergerakan ROA, yaitu variabel CAR, FDR, BOPO dan NPF.

\section{TINJAUAN PUSTAKA}

\section{Teori Agency Cost}

Teori agency cost menjelaskan adanya "agen" yang berfungsi menjalankan usaha dari pemilik (prinsipal). Setiap pihak memiliki kepentingan sendiri. Para manajer yang berfungsi sebagai agen menghendaki perusahaan berkembang, meski harus mengambil risiko dan tertahannya laba mengalir ke pemilik saham. Para pemilik saham menghendaki terhindarnya risiko dan laba mengalir kepada mereka (Jensen \& Meckling, 1976). Biaya keagenan dikeluarkan sebagai cara untuk memonitor tindakan para manajer sehingga tidak bertindak atas kemauan sendiri, namun atas kepentingan perusahaan. Teori ini terdiri dari tiga hal berikut, yaitu (1) Biaya monitoring oleh principal, (2) Biaya bonding oleh agen, (3) Rugi residual (residual loss). Agency cost sangat relevan dengan penelitian ini, karena perbedaan kepentingan antara pemilik dan agen akan berpengaruh pada profitabilitas perusahaan.

\section{Teori Signaling}

Teori yang menjelaskan pentingnya pengukuran profitabilitas adalah teori signaling. Teori ini menyatakan bahwa perusahaan dengan keuntungan yang besar akan menggunakan informasi finansial untuk mengirimkan sinyal ke pasar (Spence, 1973). Macharia (2016) menjelaskan teori signaling bahwa ketika kinerja sebuah bank sangat baik, maka para direksi akan memberi sinyal tertentu yang akan memperbaiki reputasinya, yang dapat meningkatkan profitabilitas dan nilai dari perusahaannya. Laba merupakan salah satu sinyal kunci yang diperlukan, baik untuk pemilik, manajemen bank, maupun para penyimpan dana. Hal ini karena semua kebijakan bisnis dan strategi manajemen yang baik akan tercermin pada tingginya laba. 


\section{CAR}

Rasio CAR merupakan rasio untuk mengukur permodalan dalam menanggung perkreditan, terutama risiko yang terjadi karena bunga gagal ditagih (Kasmir, 2014). Pentingnya permodalan dalam perbankan membuat Bank Indonesia mewajibkan bank untuk menyediakan modal sebesar 8\% dari Aktiva Tertimbang Menurut Risiko untuk menjaga agar permodalan bank stabil dan usaha bank dapat berkembang, juga dapat menutupi kerugian yang mungkin terjadi. Rasio CAR dirumuskan dengan:

$$
\mathrm{CAR}=\frac{\text { Modal }}{\text { Aktiva Tertimbang Menurut Risiko }}\left(\begin{array}{l}
\text { (ATMR) } \\
\text { (ATM }
\end{array}\right.
$$

\section{FDR}

Rasio ini mengukur perbandingan antara jumlah pinjaman yang diberikan dengan simpanan masyarakat. Apabila hasil pengukuran jauh berada di atas target, bank tersebut berisiko mengalami kesulitan likuiditas yang pada gilirannya akan menimbulkan biaya yang besar. Sebaliknya bila berada di bawah target, bank akan mengalami tekanan pada pendapatan berupa tingginya biaya pemeliharaan kas yang menganggur (idle money). (Kuncoro M. \& Suhardjono, 2012). Rasio FDR dirumuskan dengan:

$$
\text { FDR }=\frac{\text { Jumlah Pembiayaan }}{\text { Total Dana Pihak Ketiga }} \times 100 \%
$$

\section{BOPO}

BOPO digunakan untuk mengukur level dan kemampuan bank dalam melaksanakan kegiatan operasionalnya. Bank dengan BOPO yang tinggi menggambarkan bank tersebut tidak beroperasi secara efisien nilai yang tinggi merefleksikan besarnya total pengeluaran operasional bank untuk mendapatkan pendapatan operasional (Riadi S, 2018). Rasio BOPO dirumuskan dengan:

$$
\underset{=}{\text { BOPO }} \frac{\text { Biaya (Beban) Operasional }}{\text { Pendapatan Operasional }} \times 100 \%
$$

\section{NPF}

Mengacu pada Kuncoro M. dan Suhardjono (2002), NPF adalah kondisi di mana nasabah peminjam tidak mampu membayar sebagian atau seluruh kewajibannya sesuai dengan perjanjian yang disepakati. Rasio ini dirumuskan sebagai berikut:

$$
\mathrm{NPF}=\frac{\text { Pembiayaan Bermasalah }}{\text { Total Pembiayaan }} \times 100 \%
$$

\section{Profitabilitas}

Menurut Kuncoro \& Suhardjono (2002) salah satu rasio yang digunakan untuk mengukur dan membandingkan kinerja profitabilitas bank adalah ROA. Indikator ini menunjukkan kemampuan manajemen bank dalam menghasilkan pendapatan dari manajemen aset yang dimiliki. 
Oleh karena itu semakin besar ROA, maka semakin besar pula tingkat keuntungan yang akan diperoleh oleh para pemegang saham. Rasio ROA dirumuskan dengan:

$$
\underset{=}{\text { ROA }} \frac{\text { Laba Sebelum Pajak }}{\text { Total Aset Rata-rata }} \times 100 \%
$$

\section{METODE PENELITIAN}

\section{Rancangan Penelitian}

Penelitian ini bertujuan untuk menguji hipotesis, yang di dalamnya terdapat hubungan antara variabel independen terhadap variabel dependen. Rancangan penelitian ini menguji pengaruh variabel CAR, FDR, BOPO dan NPF terhadap ROA BUS di Indonesia.

\section{Populasi dan Sampel Penelitian}

Populasi pada pengertian umum adalah total angka dari penduduk yang menempati suatu area pada waktu tertentu. Populasi dalam metode kuantitatif adalah jumlah semua hal atau elemen yang akan diteliti, sedangkan sampel adalah bagian dari populasi, yaitu jumlah lebih kecil yang diambil dari populasi (Buglear, 2005). Populasi yang digunakan dalam penelitian ini adalah semua Bank Umum Syariah di Indonesia yang terdaftar di direktori Otoritas Jasa Keuangan periode 2015 - 2019. Seluruh populasi berjumlah 14 bank.

Sampel adalah bagian dari jumlah dan karakteristik yang dimiliki populasi tersebut. Pengambilan sampel menggunakan metode Purposive Random Sampling, yaitu teknik pengambilan sampel yang berdasarkan pada kelompok terpilih menurut ciri-ciri khusus yang dimiliki oleh sampel tersebut.

Kriteria bank yang dijadikan sampel dalam penelitian ini adalah:

1. Bank yang menerbitkan laporan keuangan selama 5 tahun berturut-turut dari tahun 2015 sampai tahun 2019.

2. Menyajikan laporan keuangan periode 31 Desember 2015 sampai dengan tahun 2019.

3. Menyajikan rasio-rasio CAR, FDR, BOPO, NPF dan ROA selama 5 tahun berturutturut.

Jumlah keseluruhan Bank Umum Syariah yang terdaftar di Otoritas Jasa Keuangan berjumlah 14 bank. Terdapat 12 bank yang memenuhi 3 kriteria tersebut yaitu PT. Bank Aceh Syariah, PT. BPD Nusa Tenggara Barat Syariah, PT. Bank Muamalat Indonesia, PT. Bank Victoria Syariah, PT. Bank BRI Syariah, PT. Bank Jabar Banten Syariah, PT. Bank BNI Syariah, PT. Bank Syariah Mandiri, PT. Bank Mega Syariah, PT. Bank Panin Dubai Syariah, PT. Bank Syariah Bukopin, PT. BCA Syariah.

\section{Teknik Analisis Data}

Penelitian ini bertujuan menguji dan menganalisis hubungan kausal antara variabel bebas dan variabel terikat. Oleh karena itu digunakan teknik analisis Regresi linear berganda menggunakan software SPSS versi 19.0 dengan uji asumsi klasik, uji F dan uji t.

Regresi linier berganda sangat bermanfaat untuk meneliti pengaruh beberapa variabel yang berkorelasi dengan variabel yang diuji. Hubungan fungsi antara satu variabel dependen dengan lebih dari satu variabel independen dapat dilakukan dengan analisis regresi linier berganda, dimana kinerja ROA sebagai variabel dependen sedangkan CAR, FDR, BOPO dan 
NPF sebagai variabel independen Persamaan yang digunakan adalah sebagai berikut (Janie, 2012):

$$
\mathbf{Y}=\mathbf{a}+\mathbf{b}_{1} \mathbf{X}_{1}+\mathbf{b}_{2} \mathbf{X}_{2}+\mathbf{b}_{3} \mathbf{X}_{3}+\mathbf{b}_{4} \mathbf{X}_{4}+\mathbf{e}
$$

Keterangan :

Y : variabel dependen ROA periode 2015 - 2019

a : konstanta

$\mathrm{X}_{1}$ : variabel independen CAR periode 2015 - 2019

$\mathrm{b}_{1}$ : Koefisien variabel $\mathrm{X}_{1}$

$\mathrm{X}_{2}$ : variabel independen FDR periode 2015 - 2019

$\mathrm{b}_{2}$ : Koefisien variabel $\mathrm{X}_{2}$

$\mathrm{X}_{3}$ : variabel independen BOPO periode $2015-2019$

$\mathrm{B}_{3}$ : Koefisien variabel $\mathrm{X}_{3}$

$\mathrm{X}_{4}$ : variabel independen NPF periode $2015-2019$

$\mathrm{b}_{4}$ : Koefisien variabel $\mathrm{X}_{4}$

e : Residual

\section{Teknik Pengumpulan Data}

Metode pengumpulan data yang digunakan dalam penelitian ini adalah teknik pengumpulan dokumentasi data arsip (archival) yang berupa data sekunder. Menurut Buglear (2005), data sekunder adalah data yang telah dikumpulkan oleh orang lain. Data dan dokumen yang dikumpulkan disesuaikan dengan kebutuhan penelitian, selanjutnya peneliti mempelajari dokumen-dokumen tersebut.

Penulis menggunakan metode pengumpulan data sekunder melalui sumber sumber berupa studi literatur yang berasal dari jurnal ilmiah, tesis, buku pegangan serta data-data dari ROA, CAR, FDR, BOPO dan NPF dari berbagai situs internet yang mendukung.

\section{HASIL DAN PEMBAHASAN}

\section{Hasil Analisis Data}

Pengujian hipotesis dilakukan untuk menguji hipotesis yang diajukan. Hipotesis yang diajukan dalam penelitian ini terkait variabel CAR, FDR, BOPO dan NPF terhadap ROA BUS di Indonesia. Analisis regresi berganda dipilih untuk menganalisis pengajuan hipotesis dalam penelitian ini.

\section{Uji F (Simultan)}

Uji variabel secara simultan dilakukan untuk menguji apakah variabel-variabel bebas secara bersama-sama berpengaruh terhadap variabel terikat, ditunjukkan dengan nilai signifikansi yang lebih kecil dari 0.05 (Janie, 2012). Jadi menguji signifikansi pengaruh CAR, FDR, BOPO dan NPF secara bersama-sama terhadap ROA. Rumusan hipotesis nol (H0) dan hipotesis alternatif (Ha) mengenai pengaruh variabel pelatihan terhadap prestasi kerja karyawan sebagai berikut:

H0 : tidak ada pengaruh pengaruh CAR, FDR, BOPO dan NPF terhadap ROA BUS di Indonesia.

$\mathrm{Ha}$ : ada pengaruh pengaruh CAR, FDR, BOPO dan NPF terhadap ROA BUS di Indonesia.

Kriteria pengambilan keputusan adalah sebagai berikut :

a. diterima jika Fhitung $\leq$ Ftabel pada $\alpha=5 \%$ 
b. diterima jika Fhitung > Ftabel pada $\alpha=5 \%$

Hasil dari pengujian variabel secara simultan dapat dilihat pada tabel berikut:

Tabel 1. Hasil Analisis Regresi Linear Berganda

\begin{tabular}{|c|c|c|c|c|c|c|}
\hline \multicolumn{7}{|c|}{$\operatorname{ANOVA}^{a}$} \\
\hline \multicolumn{2}{|c|}{ Model } & $\begin{array}{c}\text { Sum of } \\
\text { Squares }\end{array}$ & df & $\begin{array}{l}\text { Mean } \\
\text { Square }\end{array}$ & $\mathrm{F}$ & Sig. \\
\hline \multirow[t]{3}{*}{1} & Regression & 74.352 & 4 & 18.588 & 324.233 & $.000^{\mathrm{b}}$ \\
\hline & Residual & 2.809 & 49 & .057 & & \\
\hline & Total & 77.161 & 53 & & & \\
\hline
\end{tabular}

a. Dependent Variable: Return On Asset

b. Predictors: (Constant), Finance to Deposit Ratio, Non Performing Finance,

Capital Asset Ratio, Biaya Operasional Pendapatan Operasional

Sumber : Data hasil output SPSS 19 tahun 2020

\section{Uji t (Parsial)}

Uji t atau uji secara parsial dilakukan untuk melihat seberapa jauh masing-masing variabel independen berpengaruh terhadap variabel dependen. Suatu variabel dikatakan berpengaruh jika memenuhi kriteria yaitu nilai signifikansi di bawah atau kurang dari 0.05 (Janie, 2012). Berdasarkan perhitungan statistik dengan menggunakan program SPSS 19 yang termuat dalam tabel di bawah ini:

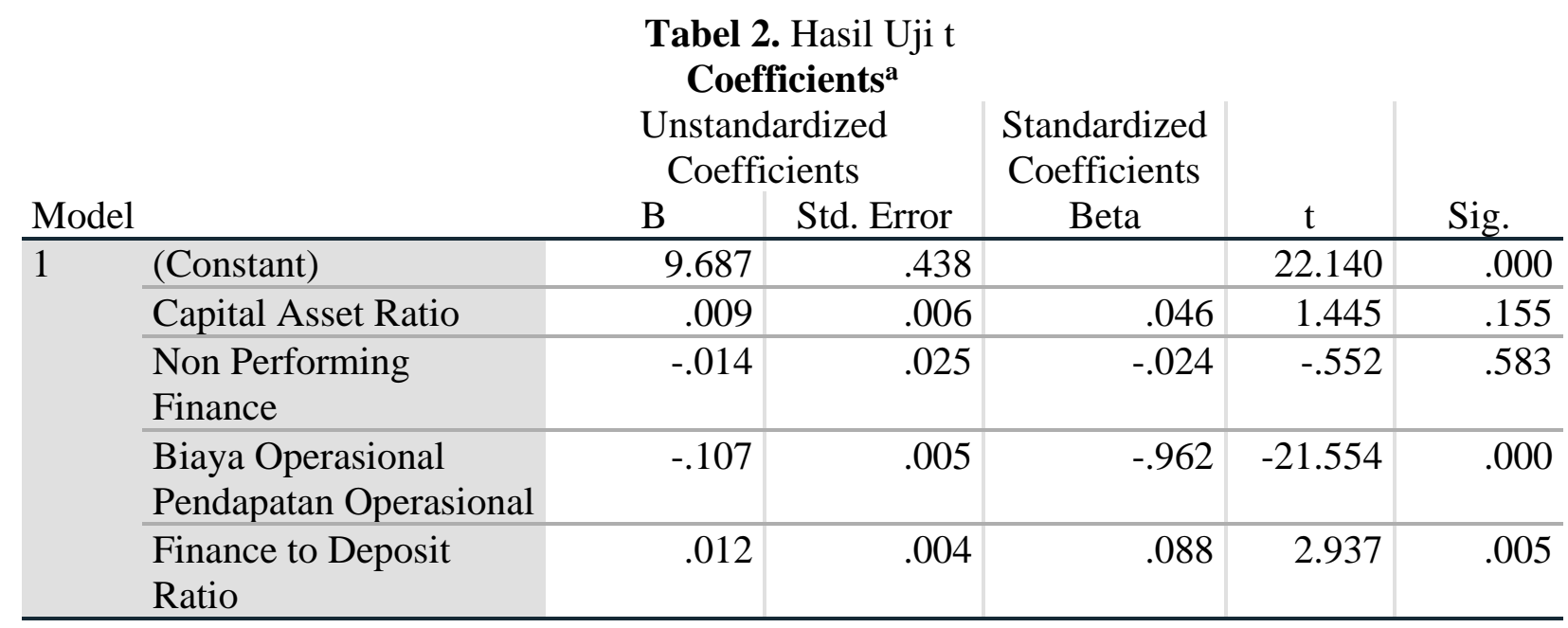

a. Dependent Variable: Return On Asset

Sumber : Data output SPSS 19 tahun 2020

Berdasarkan tabel 2 dengan perhitungan statistik menggunakan menggunakan program SPSS 19 di peroleh hasil CAR CAR terhadap ROA pada tingkat signifikansi 0,05 diperoleh nilai signifikansi t sebesar 0,155 (signifikansi t >0,05), maka $\mathrm{H}_{0}$ diterima (Ha ditolak). Variabel FDR dengan signifikansi sebesar 0,005 (signifikansi $\mathrm{t} \leq 0,05)$ maka $\mathrm{H}_{0}$ ditolak (Ha diterima). Variabel Biaya Operasional per Pendapatan Operasional (BOPO) memiliki signifikansi sebesar 0,000 (signifikansi $\mathrm{t} \leq 0,05$ ), maka $\mathrm{H}_{0}$ ditolak (Ha diterima). Variabel NPF mempunyai signifikansi sebesar 0,583 (signifikansi $\mathrm{t}>0,05$ ), maka $\mathrm{H}_{0}$ diterima (Ha ditolak). 


\section{Implikasi Hasil Penelitian}

Dari hasil yang dilakukan oleh peneliti yang diperoleh melalui uji secara analisis regresi berganda, menunjukan bahwa variabel CAR, FDR, BOPO dan NPF terhadap ROA BUS di Indonesia secara simultan berpengaruh signifikan. Secara terpisah, variabel BOPO dan FDR berpengaruh signifikan terhadap ROA. Oleh karena itu para manajer BUS memperhatikan perkembangan FDR dan BOPO secara cermat dan lebih memprioritaskan dibandingkan dengan parameter yang lain.

BOPO merupakan penentu yang penting dalam meningkatkan profitabilitas, misalkan dengan melakukan efisiensi berupa penutupan gerai atm dan berfokus pada penguatan sistem dalam jaringan (e-channel), maka biaya operasional diproyeksi akan berkurang dengan pendapat operasional relatif stabil. BOPO akan berkurang dan profitabilitas akan meningkat.

FDR merupakan variabel lain yang penting untuk menaikkan angka profitabilitas. Ketika penyaluran pembiayaan mengalami kelesuan, manajer BUS selayaknya berfokus untuk menarik pekerja berpenghasilan tetap seperti PNS, TNI/Polri, BUMN dan karyawan swasta dengan penghasilan stabil untuk memilih BUS sebagai tempat mendapatkan pembiayaan. Prinsip hati hati tentu tetap diperhatikan, namun perkembangan keuntungan BUS tetaplah bersumber utama dari pendapatan bagi hasil pembiayaan. Manajer BUS tetaplah harus memprioritaskan agar perkembangan FDR selalu sesuai dengan target, demi menjaga profitabilitas.

Variabel CAR dalam penelitian ini meskipun tidak berpengaruh signifikan terhadap profitabilitas, tetapi bukan berarti bahwa para manajer BUS mengabaikan variabel tersebut. Sebentar lagi tiga BUS utama di Indonesia, yaitu BSM, BRI Syariah dan BNI Syariah akan bergabung menjadi Bank Syariah Indonesia (BSI). Keputusan tersebut membuat BSI termasuk dalam sepuluh besar BUS dengan aset terbesar di dunia. Pilihan untuk bergabung ini tentu bukan keputusan mudah, namun sudah saatnya BUS Indonesia menuju langkah baru, tentunya dengan CAR yang meningkat, profitabilitas diharapkan akan naik.

\section{KESIMPULAN DAN SARAN}

Berdasarkan hasil pegolahan dan analisis data mengenai pengaruh CAR, FDR, BOPO dan NPF terhadap profitabilitas BUS di Indonesia dapat ditarik kesimpulan bahwa seluruh variabel independen secara simultan berpengaruh signifikan terhadap profitabilitas BUS di Indonesia. Variabel CAR dan NPF secara parsial tidak tidak berpengaruh signifikan terhadap profitabilitas BUS periode 2015 - 2019. Variabel FDR dan BOPO secara parsial berpengaruh signifikan dengan arah negatif terhadap profitabilitas BUS periode 2015 - 2019.

Dari pembahasan dan kesimpulan yang telah dilakukan, maka penulis mengajukan beberapa saran yaitu BUS disarankan untuk memperbaiki BOPO, langkah-langkah yang dapat diambil misalnya melakukan optimalisasi sistem dalam jaringan (e-channel), investasi di bidang IT, mengurangi biaya operasional (perjalanan dinas sampai penutupan kantor cabang yang kurang efektif). BUS juga harus lebih fokus pada keunggulan spesifik BUS, yaitu memecahkan masalah umat dengan sistem ekonomi islam. BUS harus lebih melaksanakan edukasi masyarakat luas mengenai keuntungan menggunakan sistem ekonomi ini. Sesuai dengan pendapat Jaya, dkk (2019), bahwa pendidikan juga bisa disebut sebagai usaha untuk meningkatkan pengetahuan umum seseorang termasuk di dalamnya penguasaan teori untuk memutuskan pesoalan-persoalan yang menyangkut kegiatan pencapaian tujuan perusahaan. BUS hendaknya meningkatkan rasio FDR ke nasabah nasabah yang potensial dengan tetap memperhatikan tingkat risiko. Pembiayaan yang efektif akan membantu meningkatkan keuntungan BUS, sekaligus menjalankan roda ekonomi masyarakat. Rekomendasi untuk penelitian selanjutnya, hendaknya menambahkan variabel lain yang tidak 
termasuk dalam penelitian ini, tapi berpengauh terhadap variabel dependen profitabilitas BUS.

\section{DAFTAR PUSTAKA}

Agustina, dkk. (2017). MSMEs Challenges in Phenomena of Disuprtion Era. Journal of Economics and Sustainable Development. Vol 8, No. 21.

Akbar, dkk. (2018). Pengaruh Kredit Macet terhadap Profitabilitas melalui Kecukupan Modal, Biaya dan Pendapatan Operasional. Jurnal Bisnis dan Manajemen FEB Universitas Brawijaya Malang. Vol. 5 No. 1.

Almunawwaroh, A., Marliana, R. (2018). Pengaruh CAR, NPF dan FDR terhadap Profitabilitas Bank Syariah di Indonesia. Amwaluna: Jurnal Ekonomi dan Keuangan Syariah. Vol. 2 No. 1.

Ascarya, Yumanita D. (2005). Bank Syariah: Gambaran Umum. Jakarta: Bank Indonesia.

Aymen, M., Boubaker, A. (2020). The Impact of Liquidity on Bank Profitability: Case of Tunisia. European Journal of Accounting. Vol. 8 No. 2

Bernardin, D. E. Y. (2016). Pengaruh CAR dan LDR terhadap Return On Assets. Ecodemica. Vol. IV No. 2.

Case, K. E., Fair, R. C., Oster, S. E. (2017). Principles of Economics. Edinburg Gate, England: Pearson Education Limited.

Diknawati, D. A. (2014). Analisis Pengaruh CAR, NPF, FDR, dan BOPO terhadap Profitabilitas Bank Umum Syariah. STIE Perbanas Surabaya.

Hughes, J. P., Mester, L. J. (2013). Measuring the Performance of Banks: Theory, Practice, Evidence and Some Policy Implications. Oxford Handbook of Banking $2^{\text {nd }}$ Edition.

Janie, D. N. A. (2012). Panduan SPSS Keuangan. Semarang: Semarang University Press.

Jaya, F. P., Sulaiman, Rusvitawati, D. (2019). Pengaruh Person Job Fit (Pj-Fit) dan Pendidikan Terhadap Kinerja Karyawan pada PT. Citra Putra Kebun Asri (CPKA). Jurnal Riset Inspirasi Manajemen dan Kewirausahaan STIMI Banjarmasin. Vol. 3 No.1.

Jensen, M. C., Meckling, W. H. (1976). Theory of The Firm: Managerial Behavior, Agency Cost and Ownership Structure. Journal of Financial Economics 3 North Holland Publishing Company.

Kasmir. (2014). Manajemen Perbankan. Jakarta: Raja Grafindo Persada.

Khairin, F. N. (2012). Analisis Perbandingan Rasio ROA dan NPL antara Bank Konvensional dan Bank Syariah (Studi pada PT. Bank Mega Tbk dan PT. Bank Mega Syariah Tbk).

Kuncoro, M., Suhardjono. (2002). Manajemen Perbankan. Yogyakarta: BPFE.

Kusumastuti, W. I., Alam, A. (2019). Analysis of Impact of CAR, BOPO, NPF on Profitability of Islamic Banks. Journal of Islamic Economic Laws. Vol. 2 No. 1.

Macharia, N. J. (2016). Determinants of Profitability of Commercial Banks in Kenya. School of Business Nairobi.

Miller, R. L. (2016). Economics Today The Macro View. Texas: Pearson.

Otoritas Jasa Keuangan. (2016). Peraturan Otoritas Jasa Keuangan Nomor 6/POJK.03/2016 Tentang Kegiatan Usaha dan Jaringan Kantor Berdasarkan Modal Inti Bank.

Otoritas Jasa Keuangan. (2020). Statistik Perbankan Syariah. https://ojk.go.id/id/kanal/syariah/data-dan-statistik/statistik-perbankan syariah/Default.aspx

O’Sullivan, Sheffrin, Perez. (2012). Macroeconomics. New Jersey: Pearson Education, Inc. 
Rendiana, Gery. (2015). Analisis Pengaruh Efisiensi (BOPO) dan Capital Adequacy Ratio (CAR) terhadap Return On Assets (ROA). Prosiding Manajemen Unisba.

Riadi, S. (2018). The effect of Third Parties Fund, Non Performing Loan, Capital Adequacy Ratio, Loan to Deposit Ratio, Return on Assets, Net Interest Margin and Operating Expenses Operating Income on Lending (Study in Regional Development Banks in Indonesia). Bandung: Proceeding on Operations Management.

Setyowati, D. H. (2019). Analisis Kinerja Keuangan Bank Umum Syariah sebagai Dampak Inefisiensi Operasional. Jurnal Maps (Manajemen Perbankan Syariah).

Spence. (1973). Job Market Signaling. The Quarterly Journal of Economics MIT Press. Vol. 87 No. 3

Sudarmawanti, E., Pramono, J. (2017). Pengaruh CAR, NPL, BOPO, NIM dan LDR terhadap ROA. Among Makarti. Vol. 10 No. 19.

Sulaiman. (2017). Analisis Penjualan dan Faktor-Faktor yang Mempengaruhinya pada Usaha Industri Kecil Meubel Kayu di Kota Banjarmasin. Jurnal Riset Inspirasi Manajemen dan Kewirausahaan STIMI Banjarmasin. Vol. 1 No.1.

Sumarlin. (2016). Analisis Pengaruh Inflasi, CAR, FDR, BOPO dan NPF terhadap Profitabilitas Perbankan Syariah. Jurnal ASSETS. Vol. 6 No. 2.

Syaifuddin, D. T. (2007). Manajemen Perbankan (Pendekatan Praktis). Kendari: Unhalu Press.

Wibisono, M. Y., Wahyuni, S. (2017). Pengaruh CAR, NPF, BOPO, FDR terhadap ROA yang dimediasi oleh NOM. Jurnal Bisnis dan Manajemen FEB Universitas Sebelas Maret. 